\title{
An engineering solution for a hillside project in Hong Kong
}

Alvin K. M. Lam BEng, MSc, CEng, MICE, MHKIE, RPE, RGE

Associate Director, Ove Arup \& Partners Hong Kong Limited, Hong Kong,

P. R. China (alvinkmlam@gmail.com) (Orcid:0000-0002-7708-2716)

With the increasing land demand in Hong Kong, some developments encroach into existing hill slopes or even natural terrain, which presents a big challenge to geotechnical engineers to produce cost-effective site formation and foundation designs. This paper showcases an example of a large-scale site formation work with the use of a $3 \mathrm{~m}$ dia. permanent contiguous bored pile wall supported by permanent tie-backs to facilitate a $\mathbf{3 8} \mathrm{m}$ deep excavation against a sloping terrain. With the use of the tie-back system, the movement of the adjacent ground was substantially reduced. This paper discusses the exceptional constraints and the construction challenges in this project, which include the limited site access, the difficult terrain with lack of suitable working platforms or flat grounds within the site, exposure to natural terrain hazards and the highly unbalanced excavation across the site. These constraints result in extensive temporary steel and earth platforms for facilitating the foundation construction and the excavation and lateral support works with a complex construction sequence. In addition, the findings of the backanalyses are presented to compare the predicted and the actual ground deformations using different soil models.

\section{Notation}

$c^{\prime} \quad$ effective cohesion at failure

E stiffness modulus of the soil

$E^{\prime} \quad$ elastic modulus

$E_{50}$ secant stiffness modulus at 50\% of the failure deviatoric stress

$E_{50, \text { ref }}$ stiffness modulus for primary loading in a drained triaxial test

$E_{\text {oed,ref }}$ stiffness modulus for primary loading in an oedometer test

$E_{\mathrm{p}} \quad$ stiffness modulus of the bored pile wall

$E_{\text {ur,ref }}$ stiffness modulus for unloading/reloading in a drained triaxial test

e void ratio

$G \quad$ shear stiffness of the soil

$G_{\text {o,ref }}$ reference shear stiffness at small strains

$K_{\mathrm{o}} \quad$ coefficient of earth pressure at rest

$k$ permeability

$I_{\mathrm{p}} \quad$ moment of inertia of the bored pile wall

$m \quad$ modulus exponent for stress dependency

$p^{\prime} \quad$ mean effective stress, $p^{\prime}=1 / 3\left(\sigma_{1}^{\prime}+\sigma_{2}^{\prime}+\sigma_{3}^{\prime}\right)$

$p_{\text {ref }} \quad$ reference pressure equal to the atmospheric pressure

$v \quad$ Poisson's ratio for loading/unloading

$\gamma \quad$ unit weight $\left(\mathrm{kN} / \mathrm{m}^{2}\right)$

$\gamma_{0.7} \quad$ shear strain at which $G$ has reduced to $70 \%$

$\sigma_{1}^{\prime} \quad$ effective major principle stress

$\sigma_{2}^{\prime}, \sigma_{3}^{\prime}$ effective minor principle stresses

$\phi^{\prime} \quad$ effective friction angle at failure

$\psi \quad$ dilation angle at failure

\section{Introduction}

The site was located between Stubbs Road and Bowen Road to the south-west of the Happy Valley Racecourse in Hong Kong. The ground level within the site varied from $+70 \mathrm{~m}$ above Principal
Datum (mPD) at Stubbs Road to $+123 \mathrm{mPD}$ close to Bowen Road with artificial and natural slopes in various geological settings including soil and rock. The elevation along the site boundary at the upper hillside varied from +95 to $+115 \mathrm{mPD}$. The site location and topography are shown in Figures 1 and 2, respectively.

The slopes along the western boundary were steep with slope angle generally over $35-40^{\circ}$, while those along the southern boundary were gentler with a slope angle of around $30^{\circ}$. The proposed residential development comprises five seven-storey residential blocks, 13 three-storey houses, six two-storey houses and a clubhouse with a total gross floor area amounting to $16800 \mathrm{~m}^{2}$. A two-storey car park basement and vehicular access were provided generally across the site, making the final formation level vary from $+70.0 \mathrm{mPD}$ at the entrance level at Stubbs Road to $+85.0 \mathrm{mPD}$ at the level immediately above an existing drainage tunnel and descending to $+83.0 \mathrm{mPD}$ at the western end of the site. The existing drainage tunnel fell within the Drainage Tunnel Reserve Zone (DTRZ) regulated by the government.

\section{Ground conditions}

The site comprised occasional fill and colluvial materials near the surface, which are then underlain by highly decomposed granite (HDG) to completely decomposed granite (CDG) with various degrees of weathering. The weathering profile was found to be deeper on the northern side of the site compared with that on the southern side. At the southern portion, the rock-head comprising slightly to moderately decomposed granite was encountered at 4-15 $\mathrm{m}$ below the existing ground level (i.e. about +60 to $+107 \mathrm{mPD}$ ). At the northern portion, the rock-head varied from 20 to $45 \mathrm{~m}$ below the existing ground (i.e. about +40 to $+80 \mathrm{mPD}$ ). The rock-head level within the DTRZ varied from +60 to $+95 \mathrm{mPD}$. The rock-head levels rose towards the hillside with the levels near the Bowen Road level varying from +95 to $+110 \mathrm{mPD}$. A deep weathering profile with thick 


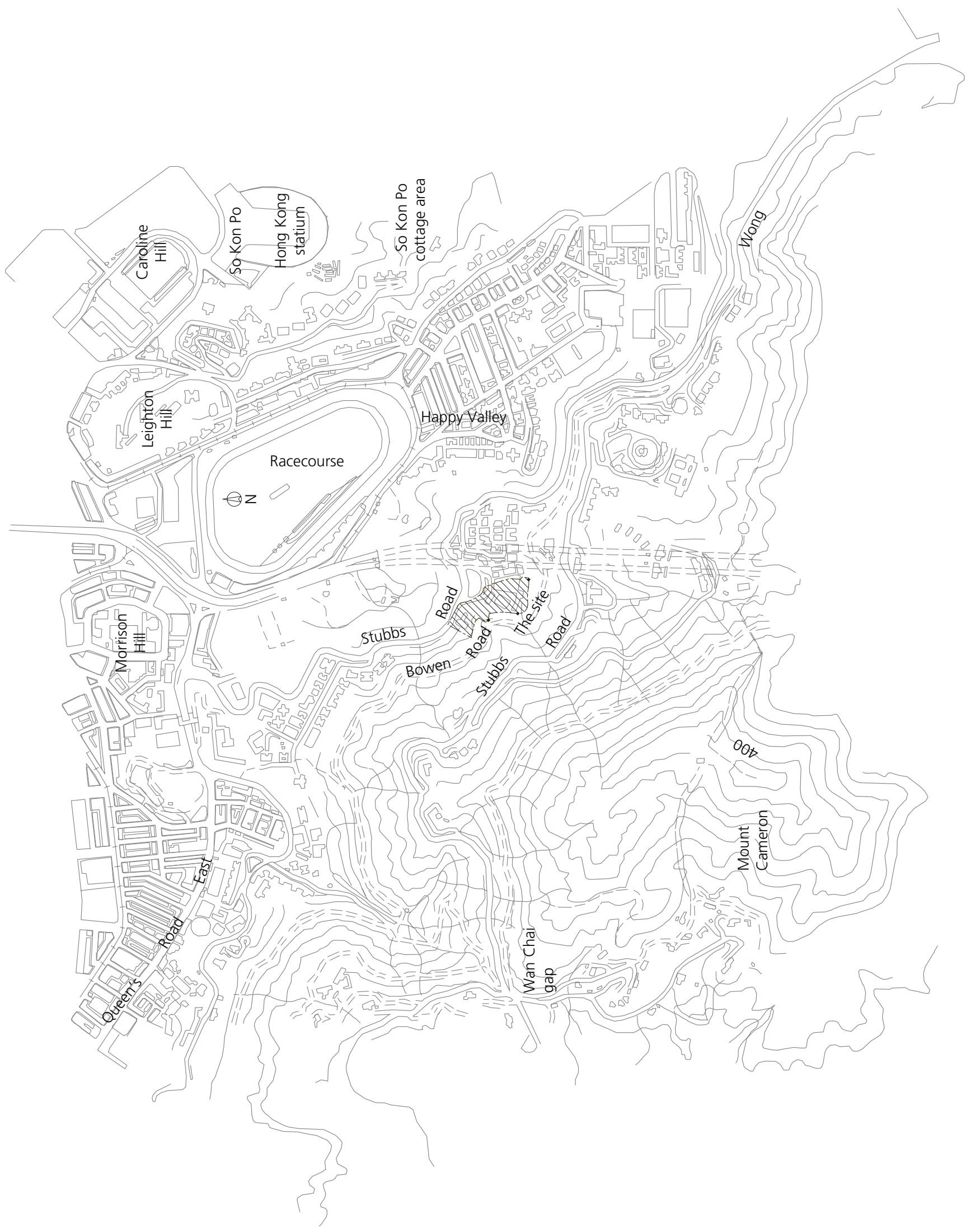

Figure 1. Site location 


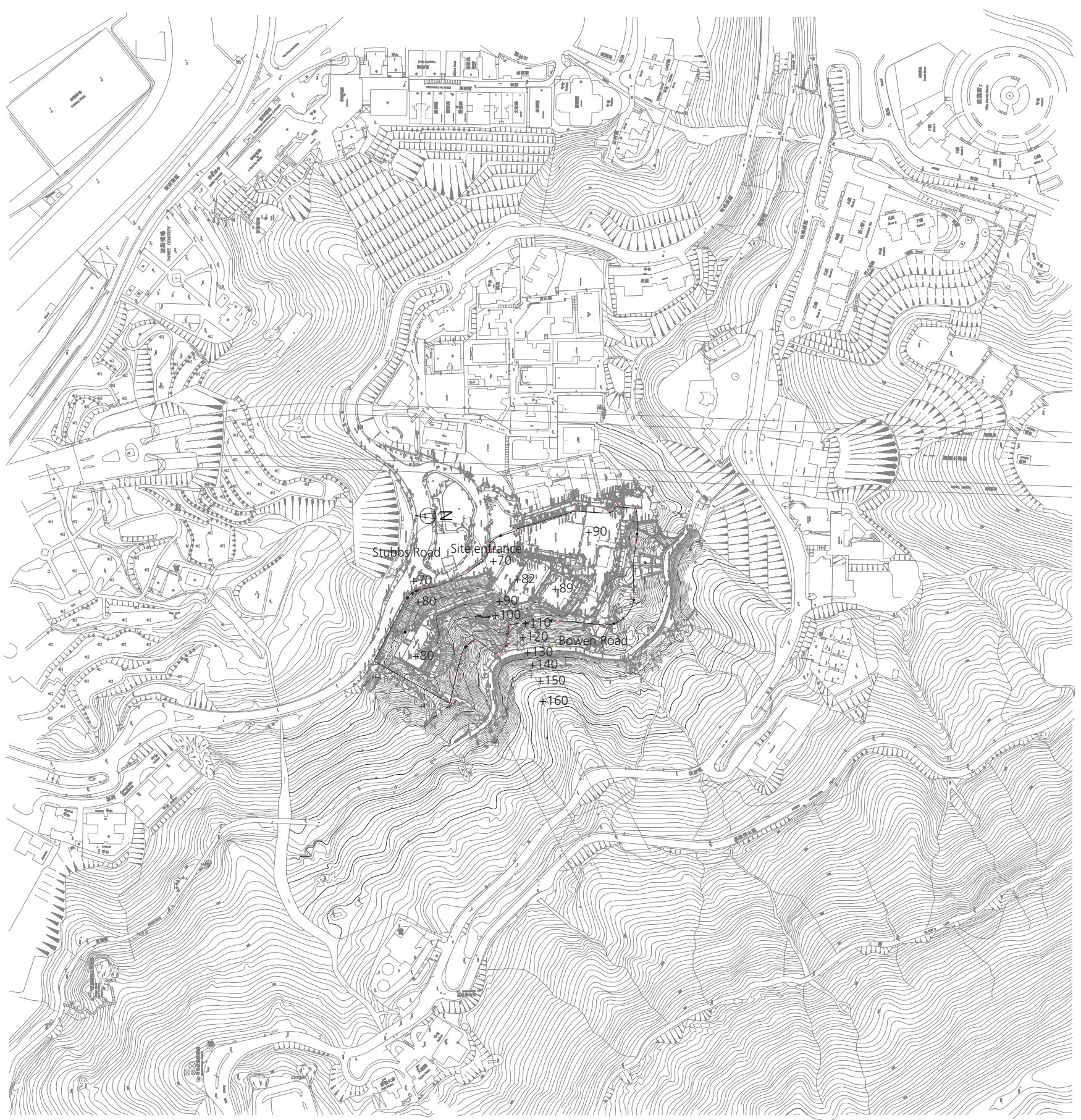

Figure 2. Site topography

corestones was identified at the northern portion of the site, while the rock-head profile was more distinctive at the southern portion without significant thickness of corestones.

\section{Considerations and evolution of the bored pile wall with tie-backs}

The design of the site formation works for this project was governed by the following factors.
- Vehicular access. Based on the topographic survey, starting from the site entrance and going clockwise, the ground level along the site boundary varied from $+70 \mathrm{mPD}$ at Stubbs Road and gradually rose to $+105 \mathrm{mPD}$ at the south-eastern corner of the site. The ground level maintained at this level with local variations along the western perimeter and climbed to $+115 \mathrm{mPD}$ above the DTRZ. The ground then dropped gradually to $+95 \mathrm{mPD}$ at the western corner and returned to 
Stubbs Road level at $+64 \mathrm{mPD}$. Vehicular access needed to be provided linking the different portions of the site.

- Development height limit. The development of the site was subjected to a height limit at $+120 \mathrm{mPD}$, which was slightly lower than the level of Bowen Road at about $+123 \mathrm{mPD}$ such that the view at Bowen Road would not be affected.

- Existing drainage tunnel within the DTRZ. The existing drainage tunnel was located below the rock-head with crown and invert levels at +44 and $+40 \mathrm{mPD}$, respectively. The DTRZ was defined at +30 to $+55 \mathrm{mPD}$ in elevation and $25 \mathrm{~m}$ away from the centreline of the drainage tunnel on plan. The stress change and movement of the drainage tunnel due to the excavation effect and the imposition of the foundation load needed to be considered.

- Car park basement. A two-storey car park basement was provided generally across the site. In view of the site topography and the height limit, the car park basement needed to be housed below the existing topography.

- Existing tree. A tree located south-west of the site was required to be protected under the lease by maintaining the existing ground level between +90 and $+99 \mathrm{mPD}$ in a circular area of $7.5 \mathrm{~m}$ radius from the centre of the tree.

With these considerations, multiple building platforms were proposed across the site and were raised towards the south and west from the entrance at Stubbs Road. The final excavation level for the majority of the eastern portion of the site was maintained at $+70 \mathrm{mPD}$ and raised to $+85 \mathrm{mPD}$ close to the southern perimeter for the provision of the building platform for towers 1 to 3. In this area, the retained ground within the circular area of the existing tree would be approximately $10-20 \mathrm{~m}$ above the proposed formation level. Towards the western portion of the site, the proposed formation level was raised from the Stubbs Road entrance level at +70 to $+75 \mathrm{mPD}$ above the DTRZ. The building platform was further raised to $+83 \mathrm{mPD}$ where towers 5 and 6 were situated. These building platforms were mainly formed by cutting into the existing hillside/sloping ground. Various earthretaining structures in the form of permanent bored pile walls or L-shaped retaining walls were considered depending on the height of the vertical cutting. The proposed developments were founded on piles or shallow foundation bearing directly on rock. The master layout plan and the approximate excavation levels of the building platform are shown in Figure 3.

Along the western site boundary, it was proposed to form a platform at +75 to $+83 \mathrm{mPD}$ and the retaining height varied from 23 to $38 \mathrm{~m}$. In order to maintain such a substantial level difference, a large-diameter bored pile wall was proposed. Based on the available ground investigation information, about onethird to four-fifths of the retaining height was within bedrock. The rock profile was generally shallower at the southern end of the site but deepened towards the western end. The biggest challenge for the bored pile wall design was to control the ground movement within a reasonable limit in order not to cause any substantial damage or instability to the surrounding structures, geotechnical features and underground utilities, particularly under long-term conditions.

Behind the western site boundary was an undeveloped greenbelt area, which was relatively insensitive to ground movements. At approximately $30 \mathrm{~m}$ uphill behind the site was the existing Bowen Road, which was a rural path mainly used by hikers and served as an access to nearby services. A bridged crossing, water pipes and conduits were constructed along certain sections of Bowen Road. Therefore, there was a concern about ground movement at Bowen Road in order not to jeopardise the safety of the general public. In order to demonstrate the feasibility of using the bored pile wall system, preliminary analyses using a finite-element computer program were carried out to check the internal stresses and the deformation of the bored pile wall system and the ground movements behind the wall.

Two different schemes, which included the multiple rows of cantilever bored pile walls and a single row of cantilever bored pile wall together with extensive upslope stabilisation by soil nails, were first considered. However, the former scheme caused excessive upslope movement, although it was proven by the finite-element analysis that it would not trigger any upslope instability, and the latter scheme would extensively limit the development potential of the upslope areas due to the extensive installation of soil nails. In order to control better the ground movement at Bowen Road, considering the public safety concern, and to reduce the extent and number of nails, a third scheme using a single row of $223 \mathrm{~m}$ dia. bored piles at $5 \mathrm{~m}$ centres supported by 229 permanent tie-backs was developed. The advantages of this scheme are discussed as follows.

- The development potential within the upslope area outside the western site boundary was substantially improved as the tiebacks were installed in front of the bored pile wall starting at a deeper level, resulting in shorter lengths compared with the use of upslope stabilisation by soil nails. The horizontal spacing of the tie-backs followed the spacing of the bored piles, which was about three times wider than the conventional spacing between soil nails.

- The permanent tie-backs scheme offered another advantage in terms of the provision of a permanent steel casing for preventing soil collapse during the course of installation, while only a temporary casing would be used for conventional soil nails. This greatly reduced the risk of soil collapse and loss of grout during installation.

- The construction of the tie-backs would be carried out starting at levels well below the existing ground and within the lot boundary. Therefore, the disturbance to the trees outside the western site boundary was very much minimised.

- The permanent tie-backs were designed to be bonded into bedrock, which was considered to be a robust design compared with bonding soil nails into in situ soil.

- The tie-backs were installed below ground. The existing hillside appearance and vegetation would remain unaffected. 
Geotechnical Research

Volume 5 Issue GR3
An engineering solution for a hillside project in Hong Kong

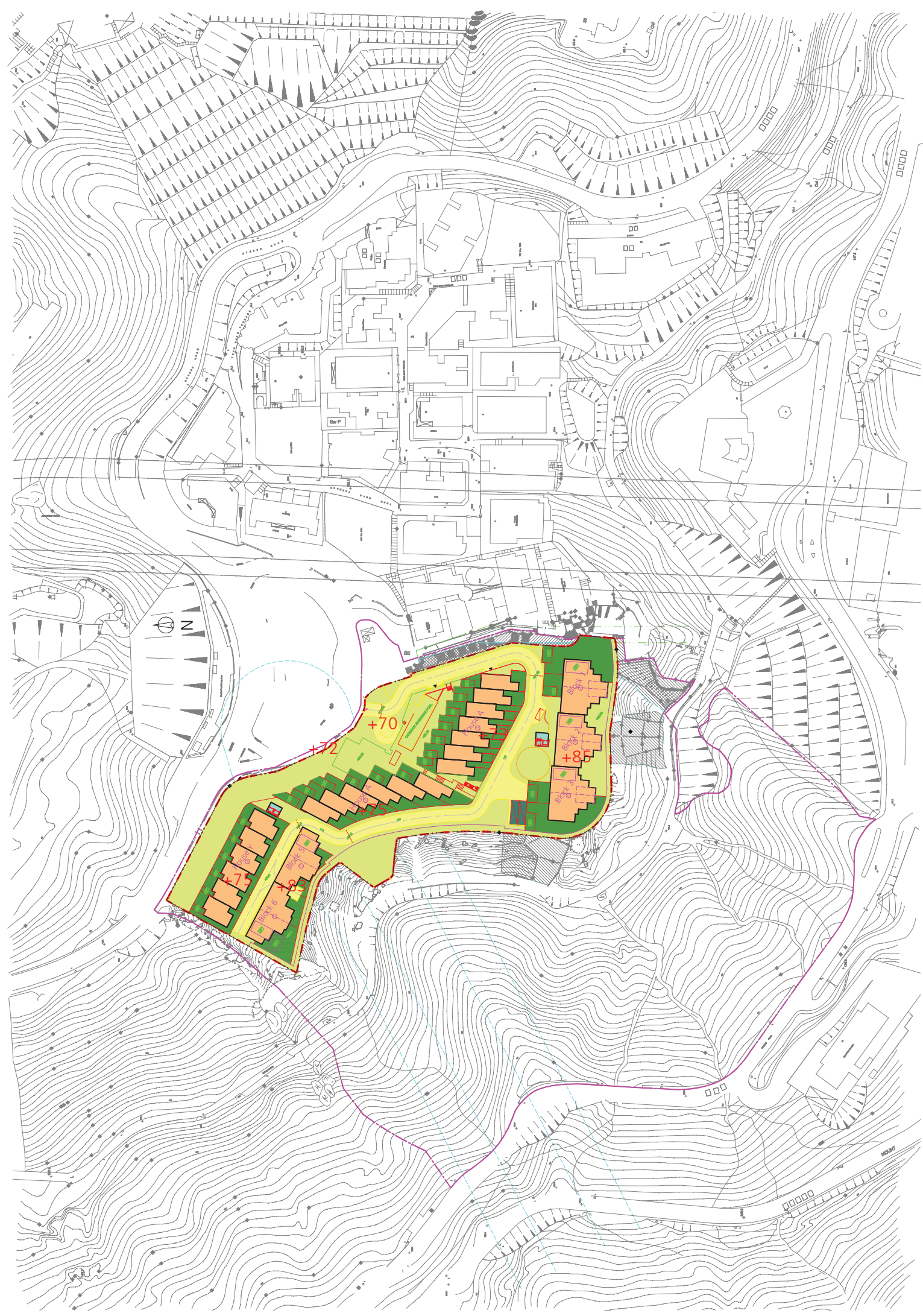

Figure 3. Site development plan 


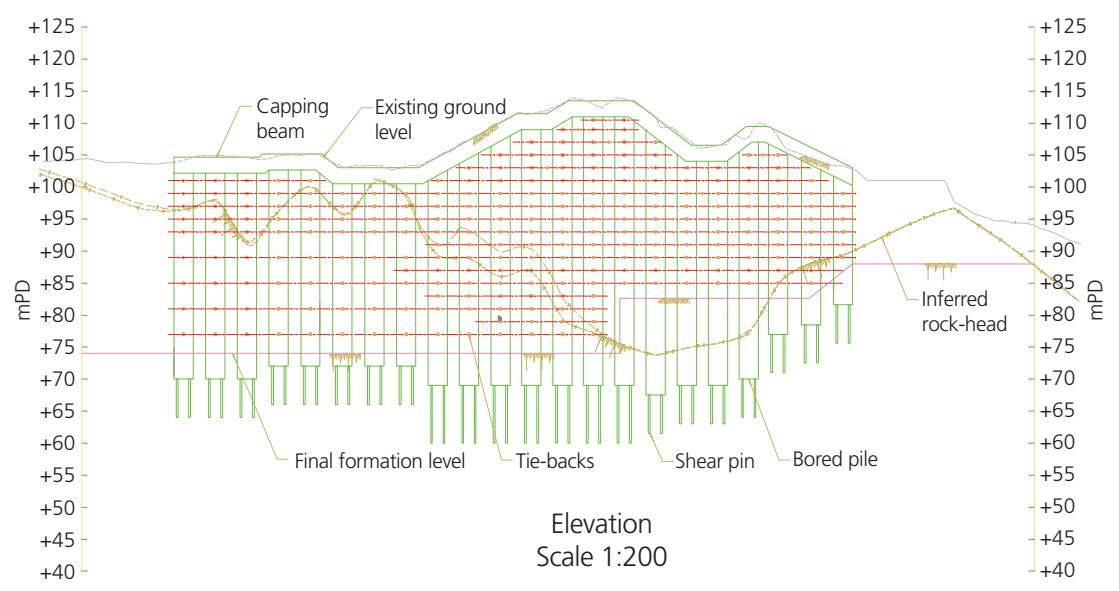

Figure 4. Bored pile wall elevation

Based on these advantages, the scheme of bored pile wall supported by permanent tie-backs was finally adopted for this project. In order to reduce the embedment depth of the bored piles, a number of shear pins consisting of 4T50 deformed bars were designed to provide the necessary shear resistance against the kick-out stability of the bored piles. The permanent tie-backs consisted of $4 \mathrm{~T} 50$ deformed bars in a $240 \mathrm{~mm}$ dia. drillhole bonded into category 1 (c) rock or better. The working capacity of the tie-backs was $2067 \mathrm{kN}$ with $8 \mathrm{~m}$ rock socket length. They were installed in front of the bored pile wall with typical vertical spacings of 2 and $4 \mathrm{~m}$ and dipping at $30^{\circ}$ when the excavation progressed downwards. The elevation of the bored pile wall is shown in Figure 4.

The site was also subjected to natural terrain hazards, which were mitigated by three rigid barriers positioned at the existing main stream courses below Bowen Road to capture the channelised debris flow and a continuous upstand wall behind the western and southern site boundary to capture any boulder falls and minor open hillside landslides. A portion of the upstand wall was integrated into the capping beam of the bored pile wall so as to minimise the construction impact on the natural terrain and the existing trees. The general view of the constructed bored pile wall and the integrated upstand wall is shown in Figure 5.

\section{Design of the bored pile wall supported by tie-backs}

The design of the bored pile wall supported by permanent tiebacks was carried out by using the finite-element model 2D Plaxis. The Mohr-Coulomb constitutive model was adopted for the geological stratum. The wall was modelled as a plate element, while the free and bond lengths of the tie-backs were modelled as node-to-node elements and a geogrid, respectively. The shear strength parameters of the soil stratum were based on the triaxial test results from the laboratory, and the ground stiffness was derived based on the empirical correlation of $2 \mathrm{~N}$ after the paper by Chan (2003), where $N$ is the mean standard penetration test

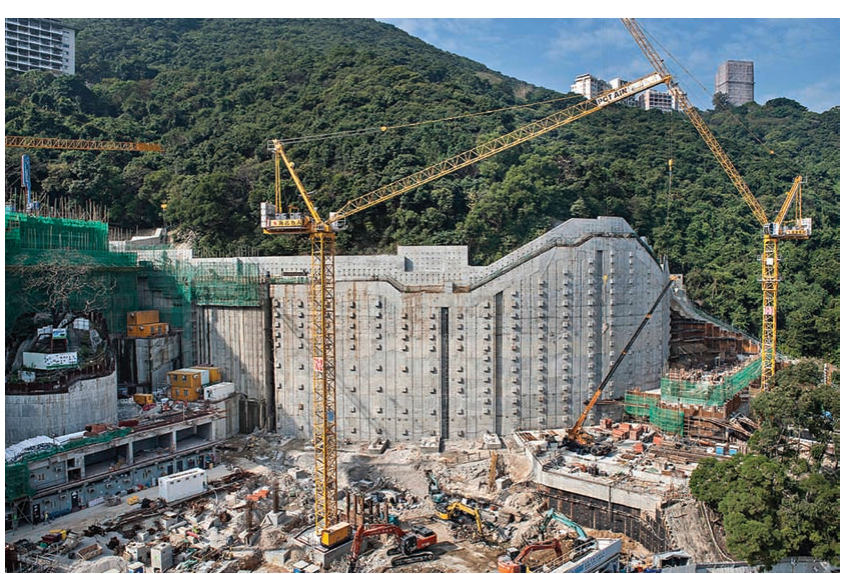

Figure 5. General view of the bored pile wall

$N$-value of the respective stratum. The rock mass shear strength parameters from the paper by Hoek (1990) were used as a reference. Based on the televiewer results, although discrete daylighting joints behind the bored pile wall were found to be kinematically feasible on the active side of the bored pile wall, the installed tie-backs served as dowel bars, which effectively stabilised any persistent daylighting joints on the active side of the wall if they existed and reduced the active pressure. In this connection, the rock mass properties were considered appropriate on both the active and passive sides of the bored pile wall. The adopted design parameters in the original design for the Plaxis analysis are summarised in Table 1.

The majority of the standpipes indicated that the measured groundwater levels were only $2 \mathrm{~m}$ slightly above or below the rock-head along the western site boundary. Using wetting band analysis, a $3 \mathrm{~m}$ high perched water table above the rock-head was assumed in the Plaxis model. Considering that the amount of groundwater within the rock mass can be readily drained away by 
Table 1. Mohr-Coulomb soil model design parameters

\begin{tabular}{|c|c|c|c|c|c|c|}
\hline Stratum & $\gamma^{\prime}: \mathrm{mm}$ & $\phi^{\prime}: \circ$ & $c^{\prime}: \mathrm{kPa}$ & $\psi^{\prime}: \circ$ & $E^{\prime}:{ }^{\mathrm{a}} \mathrm{MPa}$ & $k: \mathrm{m} / \mathrm{s}$ \\
\hline CDG & 19 & 38 & 10 & 5 & $20+5 z$ & $1 \times 10^{-5}$ \\
\hline HDG & 19 & 40 & 10 & 5 & 800 & $1 \times 10^{-5}$ \\
\hline Rock & 24 & 45 & 100 & 5 & 10000 & $1 \times 10^{-7}$ \\
\hline
\end{tabular}

${ }^{a} E^{\prime}=2 N(\mathrm{MPa})$ for $\mathrm{CDG} / \mathrm{HDG}$. ' $z^{\prime}$ refers to the depth below ground in metres

the drainage layer and the weepholes installed behind and at the lagging panels between the bored piles, no groundwater pressure was allowed beneath $3 \mathrm{~m}$ of the rock-head. The design of the bored pile wall was generally governed by the ground settlement at Bowen Road. The displacement output from Plaxis is presented in Figure 6.

The wall deflection was estimated to be about $22 \mathrm{~mm}$, while the ground movement at Bowen Road was of a similar order. The maximum load in the tie-back was well within the design capacity but was close to the limit with consideration of the impact load on the upstand wall integrated to the top of the capping beam. Prestressing of the tie-backs was not required as the tie-backs could provide enough axial stiffness to control the wall deflection as well as the upslope ground movement during the course of excavation. The design of the tie-backs generally complied with Geoguide 7, published by the Geotechnical Engineering Office (Geo, 2008). Pull-out tests and time domain reflectometry tests were performed to verify the capacity and the length of the tiebacks, respectively.

\section{Performance of the bored pile wall and back- analysis}

The performance of the bored pile wall was monitored by a total of three inclinometers embedded into three designated bored piles, 40 strain gauges installed near the head of the tie-backs, four ground settlement markers along Bowen Road and three standpipes and piezometers between the Bowen Road and the bored pile wall. After completion of the excavation work, the inclinometers recorded that the maximum wall deflection was less than $5 \mathrm{~mm}$ and the ground settlement of Bowen Road was of a similar order. The maximum force of tie-backs based on the latest measurement by the strain gauges was found to be about $850 \mathrm{kN}$, which is well within the design capacity. The piezometric head immediately behind the bored pile wall was generally below the design assumption. Comparison of the wall deflections and the tie-back forces between the design prediction and the actual measurement are presented in Figures 7 and 8, respectively.

It is not unusual that the actual ground movement is less than the design prediction. In the Plaxis model, the use of the Mohr-Coulomb constitutive model might overestimate the ground deformation under a small-strain condition. In order to simulate a more realistic soil behaviour, a back-analysis was carried out using the hardening soil small strain (HSS) model, which is an elasto-plastic advanced soil model taking the verysmall-strain stiffness and its non-linear dependency on strain level into account.

In the HSS model, three different input stiffness moduli were required to capture the soil stiffness behaviour, namely, the stiffness modulus $E_{50 \text {,ref }}$ for loading in a drained triaxial test, the

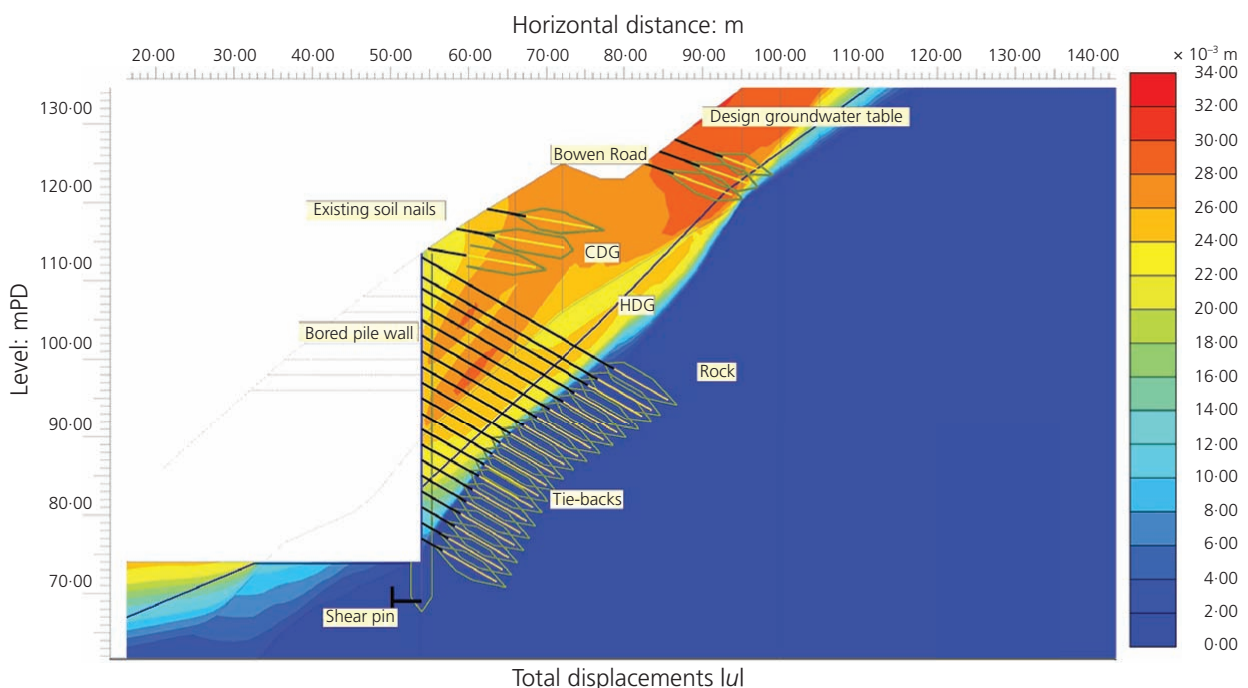

Figure 6. Displacement output from Plaxis. $|u|$, displacement output in Plaxis analysis 
An engineering solution for a hillside project in Hong Kong

Lam

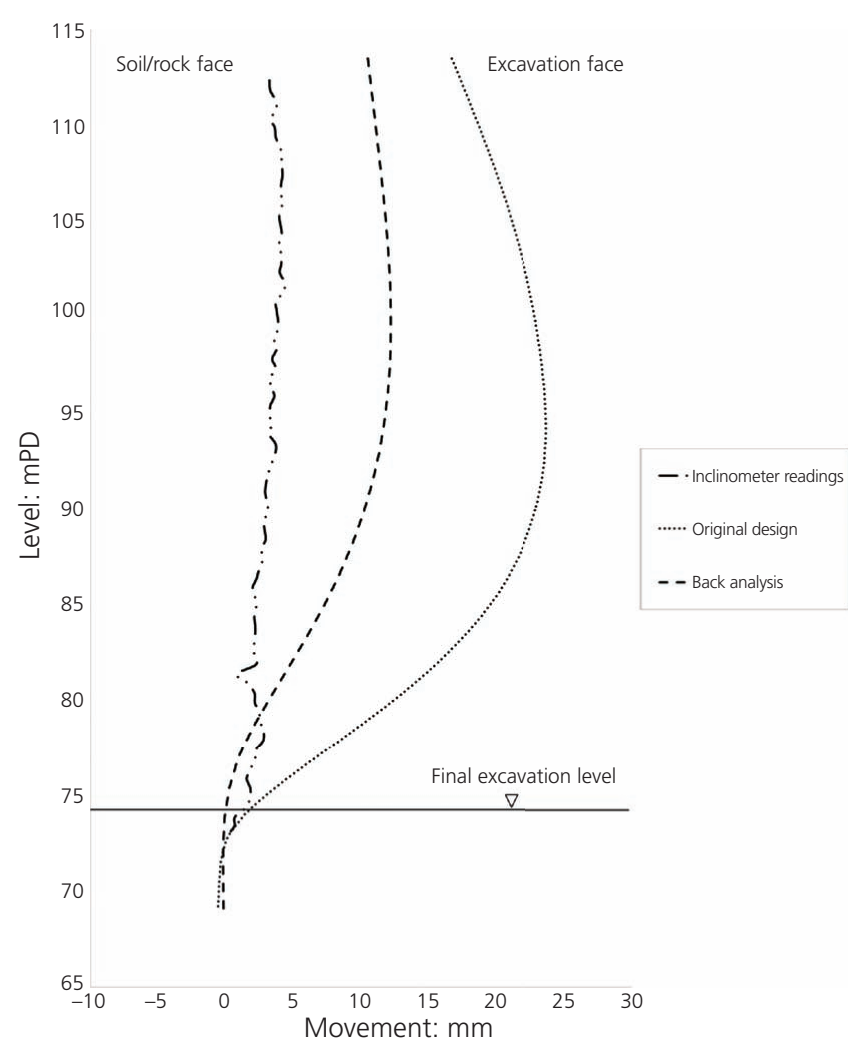

Figure 7. Comparison of wall deflections

stiffness modulus $E_{\text {ur,ref }}$ for unloading in a drained triaxial test and the stiffness modulus $E_{\text {oed,ref }}$ for loading in an oedometer test. The stiffness moduli were based on a reference pressure, $p_{\text {ref, }}$ usually set as $100 \mathrm{kPa}$. Triaxial test results were carried out at various depths of CDG samples obtained from the site during the ground investigation stage. However, no oedometer test and unloading in drained triaxial tests were carried out and the following empirical correlations were adopted

1. $E_{\mathrm{ur}, \mathrm{ref}}=3 \times E_{50, \text { ref }}$

2. $E_{\text {oed,ref }}=0.7 \times E_{50 \text {,ref }}$

Small-strain stiffness had not been captured by field and laboratory tests in this project. The paper by Hardin et al. (1969) and the thesis by Benz (2007) were used as references to establish the reference shear stiffness, $G_{\mathrm{o} \text {,ref }}(\mathrm{MPa})$, and shear strain, $\gamma_{0 \cdot 7}$, at which $G$ has reduced to $70 \%$ of the CDG material, respectively. The empirical correlations are expressed as follows

3. $G_{\mathrm{o}, \mathrm{ref}}=33 \frac{(2 \cdot 97-e)^{2}}{1+e} \sqrt{\frac{p^{\prime}}{p_{\text {ref }}}}$

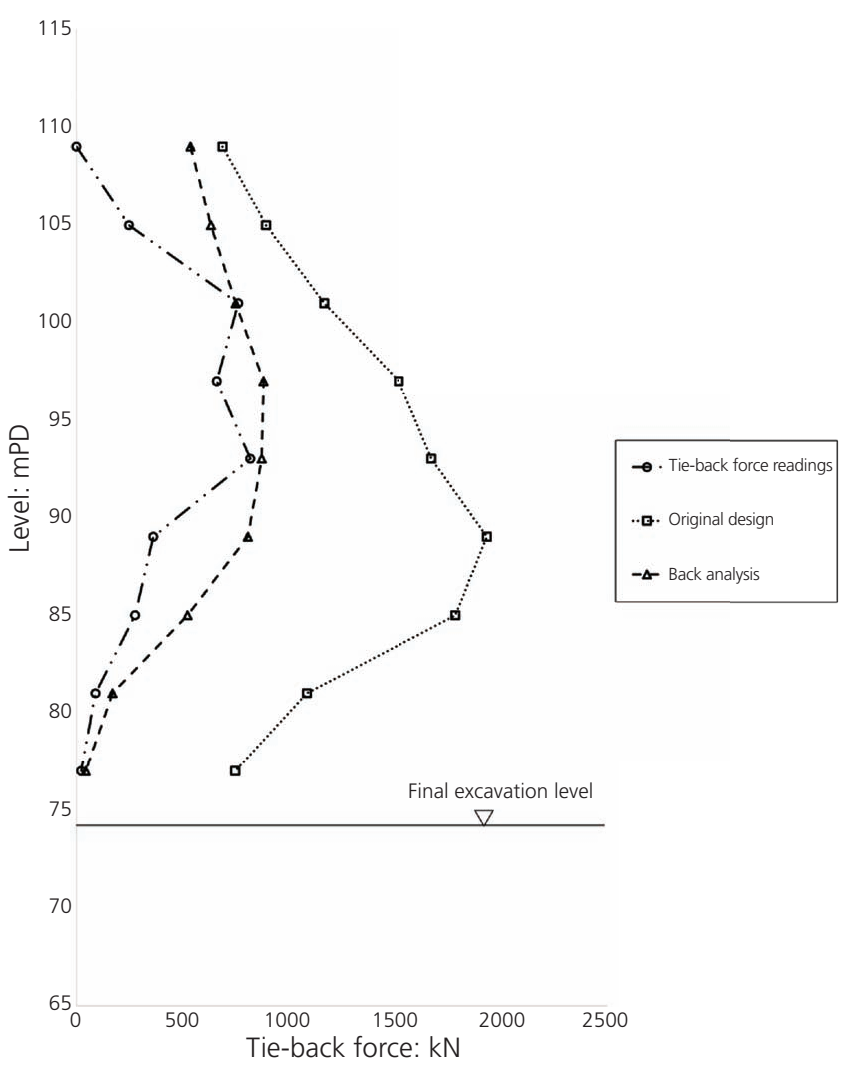

Figure 8. Comparison of tie-back forces
4.

The design shear strength and stiffness parameters of the HSS model for CDG were first calibrated by using the Plaxis virtual soil lab. The initial shear strength parameters, $c^{\prime}$ and $\phi^{\prime}$, of the HSS model were taken to be the same as those in the Mohr-Coulomb soil model. The other parameters were obtained by matching the virtual soil lab results with the actual triaxial test results. Figure 9 shows the best-fit curves between the computed and the actual triaxial test results, and Table 2 summarises the adopted parameters for the HSS model. The HSS model accounts for the stress dependency of stiffness moduli through the parameter $m$, which is typically taken as 0.5 for sandy soil and $1 \cdot 0$ for clay. The general expression for $E_{50}$ is

5. $E_{50}=E_{50, \text { ref }}\left(\frac{\sigma_{3}^{\prime}}{p_{\text {ref }}}\right)^{m}$

Poisson's ratio, $v$, is taken as $0 \cdot 3$ for medium dense material. A slightly higher dilation angle of CDG was adopted based on the 


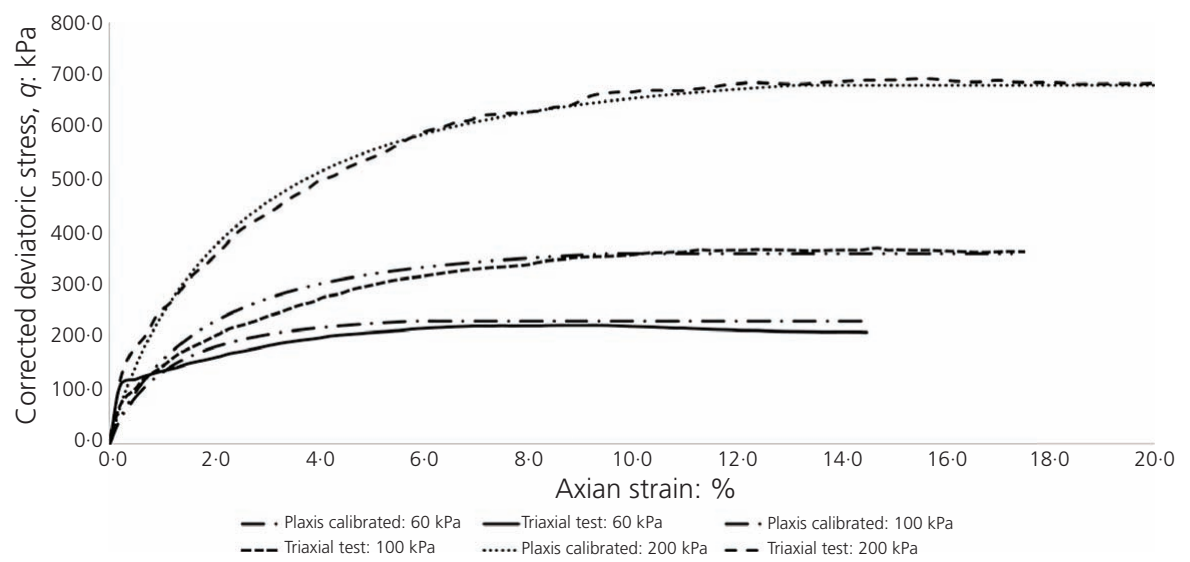

Figure 9. Best-fit curves between the computed and the actual triaxial test results

Table 2. HSS model design parameters

\begin{tabular}{|c|c|c|c|c|c|c|c|c|c|c|c|}
\hline Stratum & $\gamma^{\prime}: \mathrm{mm}$ & $\phi^{\prime}:{ }^{\circ}$ & $c^{\prime}: \mathrm{kPa}$ & $\psi^{\prime}:{ }^{\circ}$ & $E_{50, \text { ref: }} \mathrm{MPa}$ & $E_{\text {oed,ref: }}: \mathrm{MPa}$ & $E_{\text {ur, ref: }} \mathrm{MPa}$ & $m$ & $v$ & $\gamma_{0.7}$ & $G_{\text {o,ref }}: M P a$ \\
\hline$C D G$ & 19 & 38 & 10 & 8 & 15 & $10 \cdot 5$ & 45 & 0.5 & 0.3 & $1.5 \times 10^{-4}$ & 100 \\
\hline
\end{tabular}

shear box test results, which fit well with the empirical correlation of $\psi=\phi^{\prime}-30^{\circ}$.

The bored pile wall was originally modelled in Plaxis as a 'plate element' with no physical dimension. In reality, the $3 \mathrm{~m}$ dia. bored pile wall had a finite dimension, which could provide additional restoring moment due to the shaft friction developed at the back of the bored pile wall. In order to reflect this phenomenon in the model, the bored pile wall was modelled as a 'cluster' defined as a linear elastic concrete in the back-analysis. A dummy plate element was also modelled at the centre of this concrete cluster with the $E_{\mathrm{p}} I_{\mathrm{p}}$ value set to unity to capture the wall bending moment. The actual cube strength of the bored pile wall was also considered and the corresponding Young's modulus of the concrete was taken as $33 \mathrm{MPa}$. The actual measured groundwater table, which was lower than the design assumption by about $2-5 \mathrm{~m}$, was adopted. As there was lack of field and laboratory test data for estimating the small-strain behaviour of the HDG material, the Mohr-Coulomb

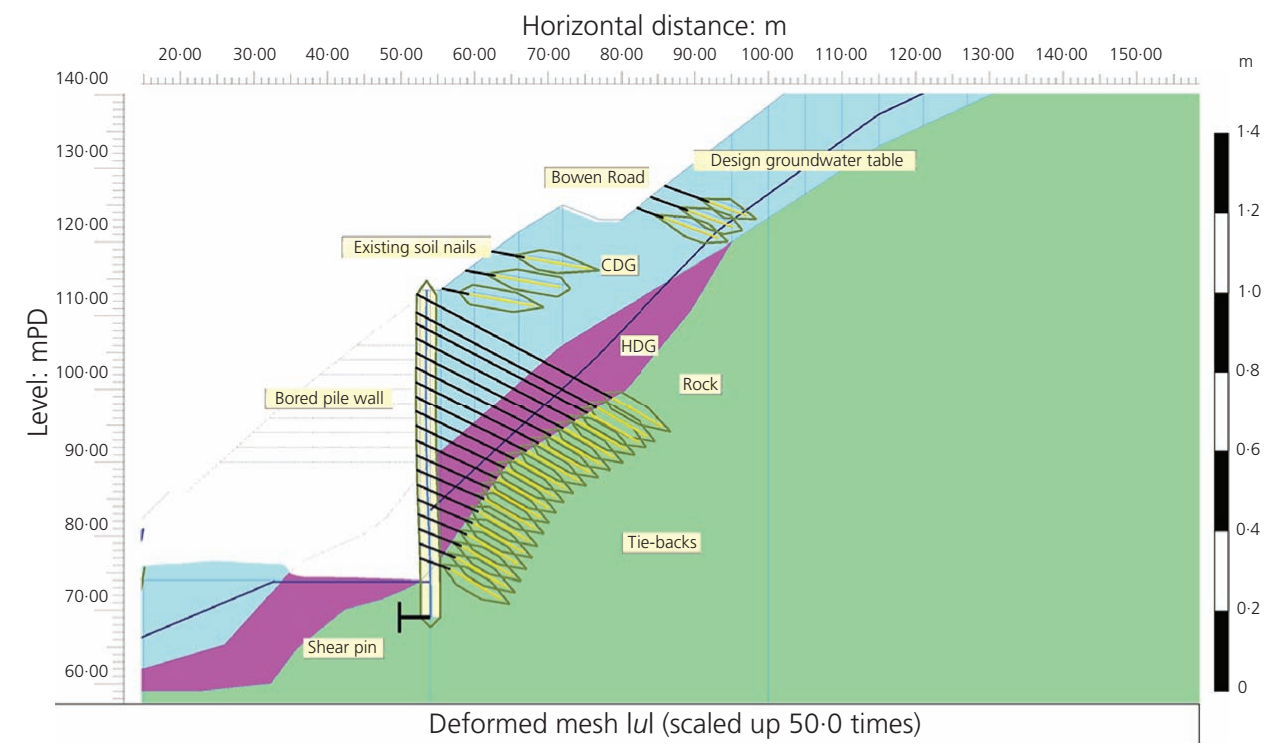

Figure 10. Deformed shape of Plaxis with concrete cluster as bored pile wall 
soil model was still used for HDG in the back-analysis. Also, considering the small deformation as recorded by the inclinometer within the rock socket, the rock mass was assumed to be an elastic continuum.

Figure 10 illustrates the deformed shape of the bored pile wall using the concrete cluster to simulate the bored pile wall in Plaxis, and Figures 7 and 8 compare the back-calculated wall deflections and the tie-back forces with the original design prediction and the actual site measurement, respectively. It can be seen that with the use of the HSS model and the concrete cluster modelling technique for the bored pile wall, the wall deflection and tie-back force were substantially reduced. The back-calculated tie-back forces also agreed well with the actual site measurement. Nevertheless, there were still limitations in the back-analysis. For instance, the arc-shaped capping beam at the top of the bored pile wall and concrete laggings constructed between the bored piles during the course of excavation provided some degree of lateral restraints to the bored pile wall system, which helped reduce the wall deflection but had not been considered in the two-dimensional analysis. The upslope geological data were also very limited.

\section{Construction challenges}

In view of the site topography as illustrated in Figure 2, one of the construction challenges was to form a site haul road linking the southern and western parts of the site over the steep terrain and the terraced platforms in order to enable the delivery of equipment, plants and materials from Stubbs Road. Temporary access ramps with gradient as steep as $1 \mathrm{~V}: 4 \cdot 5 \mathrm{H}$ were therefore formed using stacked concrete blocks and temporary fill slopes from the entrance at $+70 \mathrm{mPD}$ all the way up to the highest platform level to the south at about $+100 \mathrm{mPD}$. To the western end, the existing slope was cut back and supported by additional soil nails in order to widen the existing walkway to about $3 \mathrm{~m}$ and reaching the western platform at about $+80 \mathrm{mPD}$. Safety measures including limiting the loading condition of trucks, sufficient wheel wedges, and lookout men are strictly controlled on-site.

In order to facilitate the bored pile wall construction, a $15 \mathrm{~m}$ wide and over $100 \mathrm{~m}$ long temporary steel platform supported by vertical and raking minipiles was built on the sloping terrain within the site, which could accommodate a total of six bored pile oscillators and reverse circulation drilling rigs with four service crawler cranes to be operated simultaneously. This temporary platform fell into the critical path of the construction of the project. In order to expedite the construction process, the platform was split into three parts and the stability of the individual parts was designed to be independent from one another such that when one-third of the platform was built, the bored pile works could be started right away. The independent platforms could also allow faster dismantle. The general view of the temporary steel platform for the construction of the bored pile wall is illustrated in Figure 11.

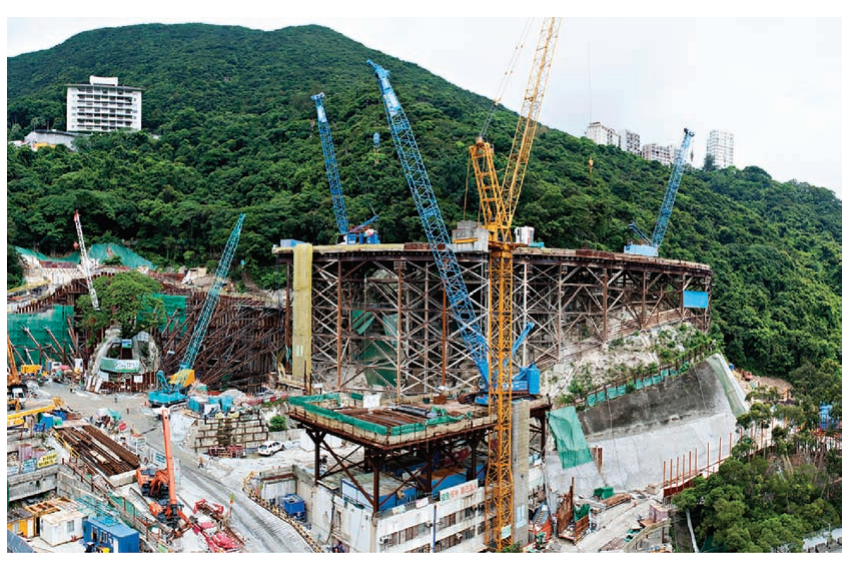

Figure 11. General view of the temporary working platform

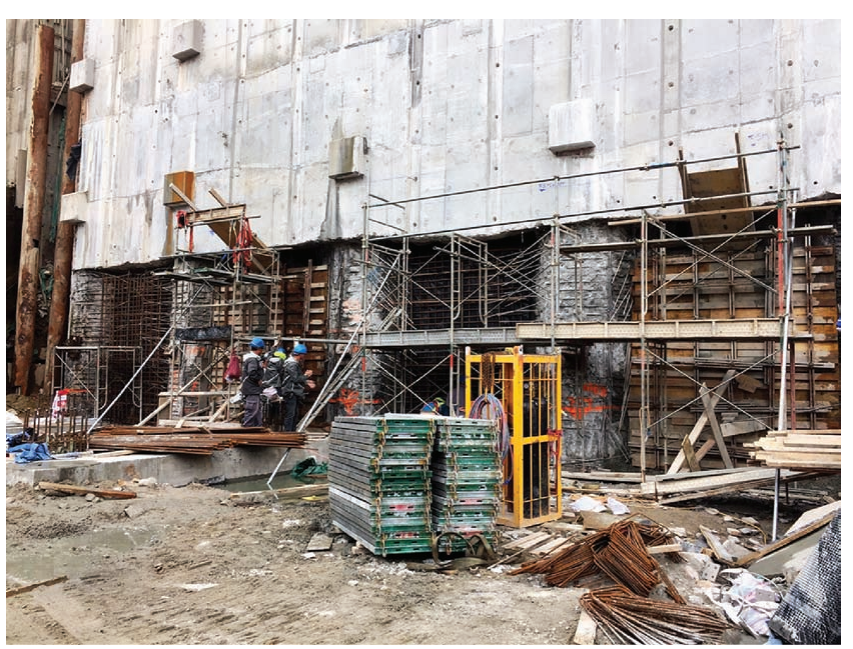

Figure 12. Concrete lagging between bored piles

In this project, a $500 \mathrm{~mm}$ thick concrete lagging with weepholes was placed at the front face of the bored pile wall. Behind the concrete lagging was the drainage blanket, which consisted of a layer of Mira drain and a $200 \mathrm{~mm}$ thick no-fines concrete for the exposed soil and rock faces, respectively, from the top of the capping beam to the final formation level. Construction of the concrete lagging between the bored piles (see Figure 12) and the preparation of the tie-back head (see Figure 13) were labour intensive and repetitive. In order to streamline the work sequence, a temporary lagging constructed by sprayed concrete was introduced such that the progress of the excavation could be expedited and the permanent lagging could be constructed afterwards.

\section{Conclusions}

Due to the proposed formation of multilevel building platforms within the site and the significant depression of the proposed formation below the surrounding topographic profile, a $38 \mathrm{~m}$ high 


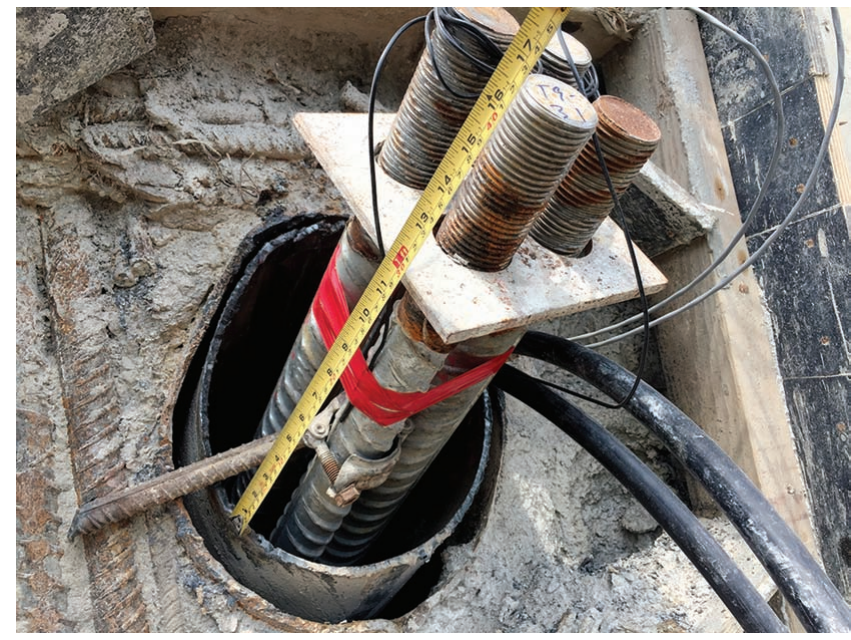

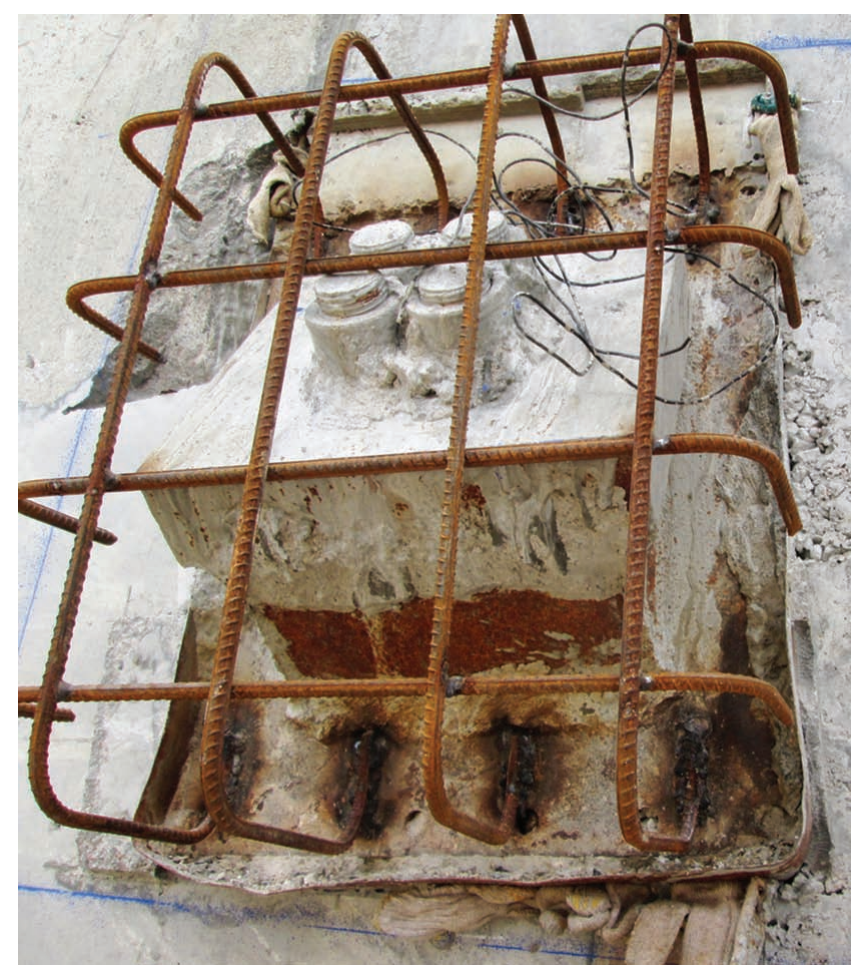

(b)

(a)

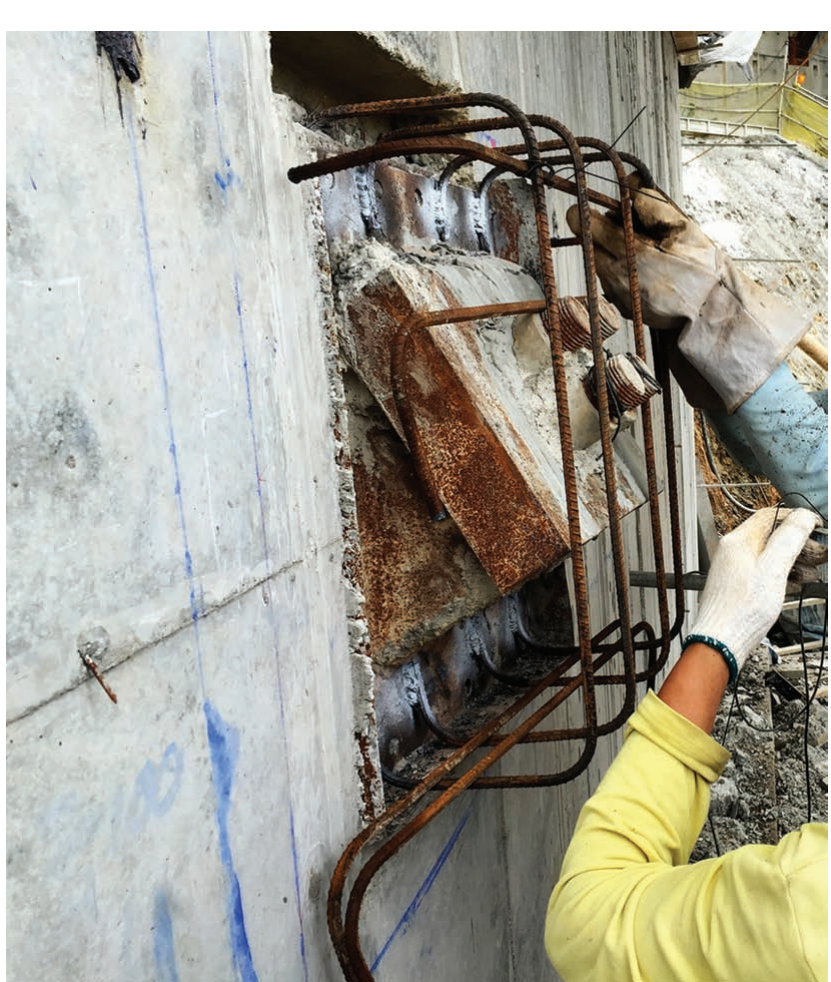

(c)

Figure 13. Tie-back head detail: (a) insertion of tie-backs into drilled hole; (b) front view of tie-back head and (c) side view of tie-back head

bored pile wall reinforced by a tie-back system was proposed to satisfy the structural and serviceability performances of the surrounding structures and slopes, which set a precedent for new developments over a hilly terrain.

Back-analyses using the 2D Plaxis and the HSS model in CDG were performed to compare the results with the original design prediction using the Mohr-Coulomb soil model as well as the actual site measurements. In lieu of using the plate element to model the bored pile wall, the use of the cluster modelling technique, which defined the bored pile wall as a linear elastic material and reflected the actual dimensions of the wall in Plaxis, was found to give a more accurate prediction for both the wall deflection and the tie-back forces.

\section{REFERENCES}

Benz T (2007) Small-strain Stiffness of Soils and Its Numerical

Consequences. PhD thesis, University of Stuttgart, Stuttgart, Germany. 
Geotechnical Research

Volume 5 Issue GR3
An engineering solution for a hillside

project in Hong Kong

Lam
Chan KC (2003) Observations from excavations - a reflection. Case Histories in Geotechnical Engineering in Hong Kong: Proceedings of the Hong Kong Institution of Engineers Seminar, Hong Kong, China, pp. 83-102.

Geo (Geotechnical Engineering Office) (2008) Guide to Soil Nail Design and Construction (Geoguide 7). Geo, Civil Engineering Department, Hong Kong, China.
Hardin BO and Black WL (1969) Vibration modulus of normally consolidated clay; closure. Journal of the Soil Mechanics and Foundations Division 95(SM6): 1531-1537.

Hoek E (1990) Estimating Mohr-Coulomb friction and cohesion values from the Hoek-Brown failure criterion. International Journal of Rock Mechanics and Mining Sciences \& Geomechanics Abstracts 27(3): 227-229, https://doi.org/10.1016/0148-9062(90)94333-O.

\section{How can you contribute?}

To discuss this paper, please submit up to 500 words to the editor at journals@ice.org.uk. Your contribution will be forwarded to the author(s) for a reply and, if considered appropriate by the editorial board, it will be published as a discussion in a future issue of the journal. 